\title{
Assessment of Toxicological Indices of Some Heavy Metals in Soil, Cabbage and Lettuce Samples Grown Along Some Rivers in Kano State, Nigeria.
}

\author{
Muktar, A. A., ${ }^{1}$ Alhassan A. J., ${ }^{1}$ Atiku, M. K., ${ }^{1}$ Pedro, S. L., ${ }^{2}$ Wudil, A. M*1 \\ ${ }^{1}$ Department of Biochemistry, \\ Bayero University, Kano, \\ ${ }^{2}$ Centre for Biotechnology Research, \\ Bayero University, Kano \\ Email: aliyuabbamuktar@yahoo.com
}

\begin{abstract}
Three samples of soil, lettuce and cabbage were collected from three sites along River Jakara (Zungeru, Airport Road and P.R.P) and River Getsi (Gama, Gayawa and Getsi) and were analyzed for Fe, Pb, $\mathrm{Zn}, \mathrm{Cu}, \mathrm{Mn}, \mathrm{Cr}, \mathrm{As}, \mathrm{Ni}, \mathrm{Cd}, \mathrm{Co}$, and $\mathrm{Hg}$ content using Atomic Absorption Spectrophotometer and the toxicological indices of the soils and vegetables were determined. The metal content of the soil exceeded the FAO/WHO approved limits in irrigation soil. $\mathrm{Pb}$ and As exceeded the approved limit in all the vegetables and levels of $\mathrm{Zn}, \mathrm{Cr}$ and $\mathrm{Cd}$ in the lettuce collected from sites along River Getsi exceeded the approved limits by FAONHO as the irrigation area were dotted with leather, paint, foam and chemical industries coupled with the activities of auto mechanics, furniture and wood processing companies. It was found that lettuce accumulated more toxic metals of $\mathrm{Pb}, \mathrm{Cr}, \mathrm{As}$, and $\mathrm{Cd}$ than cabbage with values ranging from $0.59-3.48,0.2-0.4,2.2-5.0$ and $0.6-3.12 \mathrm{mg} / \mathrm{Kg}$ respectively. The soil Pollution Load Index (PLI) in all the sites was found to be above 1 while the Degree of Contamination (Cd) was found to be from highly to extremely contaminated soils with the lowest Cd of 2.67 found in Gama while the highest was 5.35 in Getsi site. The Geometrical Index (Igeo) ranged from 0.07 in samples from P.R.P to 1.17 in samples collected from Zungeru suggesting an uncontaminated to moderately contaminated soils. The Bioaccumulation factor showed highest transfer of Fe and $\mathrm{Zn}$ in both cabbage and lettuce and most metals have Transfer Coefficient value above 1 suggesting excessive transfer. Based, on the above findings, Government at all levels should initiate policies that will mitigate the effects of heavy metals in the study area.
\end{abstract}

Keywords: Bioaccumulation, Contamination, Geometrical index, Irrigation, Pollution

\section{INTRODUCTION}

Soil is a vital ecosystem service provider for the sustenance of humanity that lies at the interface of the earth, air, water and life. Soil is composed of five constituents, namely, minerals, organic matter, living organisms, air and water. Heavy metals are naturally occurring in the soil formed by processes such as alteration and erosion of the underground geological materials (Kabir, et al., 2012). Sources of contamination of the soils are many which includes agricultural and industrial pollution, run-off and soil losses which drives the transportation of pollutants (Rodrigo-Comino et al., 2017). Contamination of the environment by heavy metals is a global phenomenon in recent years due to the fact that heavy metals persists in the soil and are non-degradable (Bazrafshan et al., 2015). Hence, majority are not detoxified but accumulates in the environment. Heavy metal refers to a 
metallic elements with a relatively high density and toxic even at lower concentration (Inobeme et al., 2014). They are metals and metalloids with densities greater than $5 \mathrm{~g} / \mathrm{cm}^{3}$ that are released into the environment through industrial, domestic and commercial activities such as industrial discharge, pesticides as well as application of manure (Tutic et al., 2015). Pollution of the soil by heavy metals has health implication especially with regards to crops cultivated on such soils (Steffana et al., 2017). Some heavy metals are essential for growth and normal functions of both plants and animals at lower levels like $\mathrm{Zn}, \mathrm{Mn}, \mathrm{Fe}, \mathrm{Cr}$, $\mathrm{Co}, \mathrm{Cu}$ and $\mathrm{Ni}$ however, large amount of any of these essential metals can cause acute or chronic toxicity diseases. Diseases such as mental lapse, kidney failure, and central nervous system disorder are a manifestation of long-term effect to heavy metal exposure in human and higher animals. For example, chronic exposure of $\mathrm{Cd}$ can lead to lung cancer, bone fractures, hypertension and kidney dysfunction. Exposure to lead ( $\mathrm{Pb}$ ) causes plumbism, anemia, nephropathy, gastrointestinal, colic, and central nervous system disorders (Hu et al., 2017).

Generally, the top layer of soil contains higher amount of pollutants. The levels of contaminant in the soil depends on the ability of soil matter to adsorb to the heavy metals as they play some important physiological roles in nature. The factors influencing the solubility of heavy metal ions in soil are $\mathrm{pH}$, conductivity and moisture content (Rakesh and Raju, 2013). Heavy metal contamination of soil, water, and atmosphere has greatly increased due to increasing anthropogenic activities leading to environmental problems affecting food quality and human health through their uptake by plants (Shaapera et al., 2013). This work is aimed at assessing the toxicological indices of some Heavy Metals in soil used for the cultivation of cabbage and lettuce from heavily populated sites along Rivers Jakara and Getsi in Kano, Nigeria.

\section{MATERIALS AND METHODS}

\section{Study Area}

This study was conducted in Kano State, Nigeria in 2019. Kano is located between Latitude $12^{\circ} 00^{\prime} \mathrm{N}$ and Longitude $8^{0} 30^{\prime} \mathrm{E}$ in Northern Nigeria with an area of $20,131 \mathrm{Km}^{2}$ and estimated Population of 20 million people. The Samples were collected between Latitude $12^{0}$ $027^{\prime} \mathrm{N}$ to $12^{0} 638^{\prime} \mathrm{N}$ and Longitude $8^{0} 527^{\prime} \mathrm{E}$ to $8^{0} 563^{\prime} \mathrm{E}$. River Jakara is the largest drainage network in the metropolitan Kano (Ibrahim and Saidu, 2010). The irrigation land is located at Jakara in Dala Local Government Area of Kano and the water source is mostly the effluent discharges from Kano metropolises, abattoir and gutters from the city (Adamu and Dawaki, 2008). Getsi River is River Jakara's tributary that flows Northeast direction thereafter drain out of Nassarawa and Gama areas of the city. The domestic waste as well as Industrial effluents from the surrounding areas of Gayawa, Bompai, Gama, Tudun Murtala and Dakata areas are released freely into the River. The basin and its tributaries is the main source of water of this area inhabited by more than five million people (Lynch et al., 2000). Samples were collected from three (3) sites along River Jakara (Zungeru $8^{0} 527^{\prime} \mathrm{E}, 1^{\circ} 027^{\prime} \mathrm{N}$, Airport Road $8^{0} 535^{\prime}$ E, $12^{0} 638^{\prime} \mathrm{N}$ and P.R.P $8^{0} 552^{\prime}$ E $12^{\circ} 056^{\prime} \mathrm{N}$ ) and three (3) sites along River Getsi (Gama $8^{0} 560^{\prime}$ E $12^{\circ} 036^{\prime} \mathrm{N}$, Gayawa $8^{0} 568^{\prime}$ E $12^{0} 053^{\prime} \mathrm{N}$ and Getsi $8^{0} 545^{\prime} \mathrm{E} 12^{0}$ $045^{\prime} \mathrm{N}$ ) 

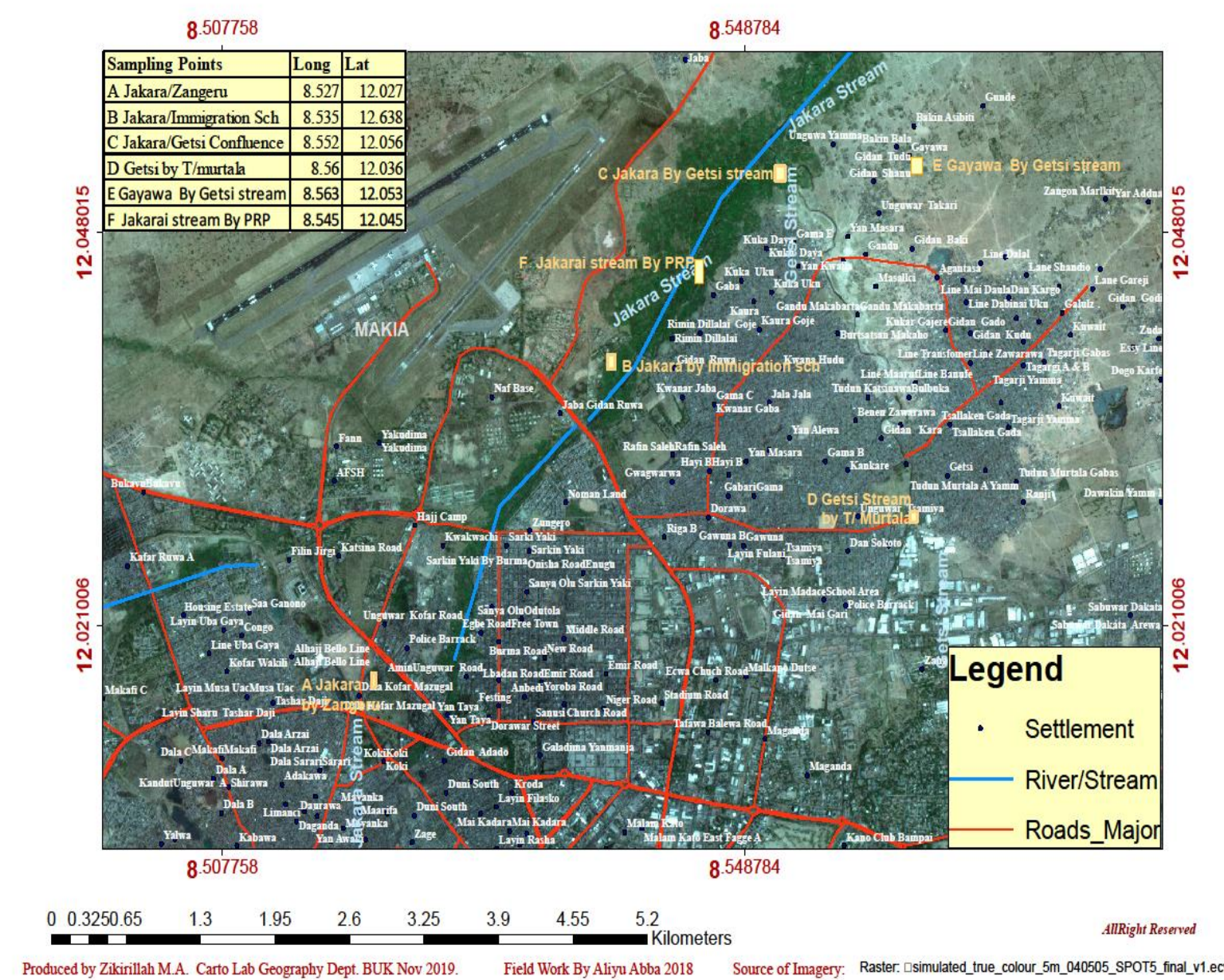

Figure 1: Map showing the study area

\section{Collection of samples}

The edible part of, cabbage (Brassica oleracea), lettuce (Lactuca sativa) and soil samples were collected and placed into a cleaned polyethylene bags. The vegetables and the soil samples were collected from farmlands with the consent of the farmers. About $1 \mathrm{~kg}$ of each were separately collected from six carefully selected subsampling sites. The bruised portions were removed while the remaining samples were carefully packed and immediately transported to Biochemistry Laboratory of Bayero University, Kano for further preparations and analyses. The vegetables were authenticated at the Plant Biology Department of Bayero University, Kano. The vegetable samples were washed to remove adsorbed soils and were then cut and chopped into small pieces using plastic knife in order to accelerate drying. This was followed by a five-day air dying and further dried in hot air oven at $40-50^{\circ} \mathrm{C}$ for 24 hours to achieve constant weight. The samples were grounded into powder using pestle and mortar and sieved with $2 \mathrm{~mm}$ mesh sieve. These were then stored in polyethylene bags inside desiccators until digestion and analysis.

\section{DIGESTION PROCEDURES OF THE SAMPLES}

A $5 \mathrm{~g}$ of the samples (soil, cabbage and lettuce) were mixed with $9 \mathrm{~mL}$ of $10 \mathrm{M} \mathrm{HNO}_{3}$ and 3 $\mathrm{mL}$ of $10 \mathrm{M} \mathrm{HCL}$ and separately placed in a tightly capped vessels and placed in the microwave digestion system which was conducted at $180^{\circ} \mathrm{C}$ for 45 minutes until a colorless solution was obtained. the clear and colorless solution was passed through Whatman No. 42 
filter paper whose volume was adjusted to $50 \mathrm{ML}$ using $2 \% \mathrm{HNO}_{3}$. The resulting solutions were immediately analyzed for heavy metals using Atomic Absorption Spectrophotometer. All samples were prepared and analyzed in triplicate and the data obtained reported as mean \pm SD. The blank was also prepared by following same procedures as per the optimum conditions established and was also analyzed (Wilson., et al, 2005)

\section{ANALYSIS OF HEAVY METAL IN THE SAMPLES.}

The level of the metals $\mathrm{Cr}, \mathrm{Cd}, \mathrm{Zn}, \mathrm{Fe}, \mathrm{Pb}, \mathrm{As}, \mathrm{Co}, \mathrm{Mn}, \mathrm{Cu}, \mathrm{Ni}$, and $\mathrm{Hg}$ in the samples were analyzed using AAS. The calibration of the instrument was carried-out using blank and five working standard solutions of individual metals that were analyzed. The calibration procedures were evaluated based on the correlation coefficients $\left(R^{2}\right)$ of the calibration curves which were found to be between 0.989 - 0.998 for all the heavy metals standards. In addition, the instrument's parameters such as fuel gas flow, speed of air pump and Nebulizer flow rate etc. were optimized for maximum signal intensity of the instrument based on the instrument's manual provided by the manufacturer.

\section{ASSESSMENT OF SOIL CONTAMINATION}

\section{Soil Contamination Factor}

The soil contamination factor (Cf) is defined as the ratio of the mean content of metal in soil from the six sites where samples were collected to the pristine concentration of individual heavy metal (Cs) (Hakanson, 1980). It is a simple and direct method of evaluation of soil quality and describes toxic substances (Inengite et al., 2015). In this work, the concentration of elements in the earth's crust was adopted as a reference value similar to Loska et al. (2004). These are the average content of the heavy metals in the Earth's crust referred to as $\mathrm{C}_{\text {ref }}$ in $\mathrm{mg} / \mathrm{kg}$ as follows: As- 6.83, $\mathrm{Cr}-59.5, \mathrm{Cu} 38.9, \mathrm{Mn}-488, \mathrm{Ni}-29, \mathrm{~Pb}-27, \mathrm{Zn}-70$ (Kabata - Pandias, 2011), Hg- 0.3, Fe $-425, \mathrm{Co}-8$ and $\mathrm{Cd}-3(\mathrm{FAO} / \mathrm{WHO}, 2011) . \mathrm{C}_{\mathrm{f}}=$ $\mathrm{C}_{\mathrm{s}} / \mathrm{C}_{(\mathrm{ref})}$

Table 1: Classification of Soil Contamination Factor

\begin{tabular}{|l|l|l|l|l|}
\hline $\mathrm{C}_{\mathrm{f}}$ & $\mathrm{C}_{\mathrm{f}}<1$ & $1 \leq \mathrm{C}_{\mathrm{f}} \leq 3$ & $3 \leq \mathrm{C}_{\mathrm{f}} \leq 6$ & $6 \leq \mathrm{C}_{\mathrm{f}}$ \\
\hline $\begin{array}{l}\text { Level of } \\
\text { Contamination }\end{array}$ & Low Contamination & Moderate Contamination & $\begin{array}{l}\text { Considerable } \\
\text { Contamination }\end{array}$ & $\begin{array}{l}\text { Severe } \\
\text { Contamination }\end{array}$ \\
\hline
\end{tabular}

\section{SOIL DEGREE OF CONTAMINATION}

The soil degree of contamination $(\mathrm{Cd})$ is defined as a sum of individual contamination factors for all trace elements $\left(\mathrm{C}_{\mathrm{f}}\right)$. $\mathrm{C} d$ parameters were categorized into four classes by Zahran et al., (2015) who developed a modification to defined ranges earlier introduced of the degree of contamination, assuming as $\mathrm{n}$ is the number of trace elements to be analyzed. $C_{d}=\sum C_{f}$ where $i=$ number of elements.

Table 2: Classification of Degree of Contamination

\begin{tabular}{|l|l|}
\hline $\mathrm{C} d$ & Soil Quality \\
\hline $\mathrm{C}_{\mathrm{d}}<\mathrm{n}$ & Low degree of Contamination \\
\hline $\mathrm{n} \leq \mathrm{C}_{\mathrm{d}} \leq 2 \mathrm{n}$ & Moderate Degree of Contamination \\
\hline $2 \mathrm{n} \leq \mathrm{C}_{\mathrm{d}} \leq 4 \mathrm{n}$ & Considerable Degree of Contamination \\
\hline $4 \mathrm{n} \leq \mathrm{C}_{\mathrm{d}}$ & Very High Degree of Contamination \\
\hline
\end{tabular}




\section{POLLUTION LOAD INDEX}

The soil pollution load index (PLI) is defined as the geometric average of the impurity coefficients (CF) and assesses the contribution of all metals in a specific place (Tomlinson et al., 1980; Jorfi et al., 2017). The parameter allows for the assessment of the level of environmental contamination in order to carryout monitoring or repair activities towards the improvement of soil quality and also allows for comparison of the level of pollution in different soil sites. It also shows the levels at which a heavy metals exceeds in natural content as it utilizes Geometric Background (GB) of each heavy metal (Sayadi et al., 2015). $\mathrm{PLI}=(\mathrm{CFs}, 1 \times \mathrm{CFs}, 2 \text {------- } \times \mathrm{CFs}, \mathrm{n})^{1 / \mathrm{n}}$ where $C F \mathrm{~s}, 1, C F \mathrm{~s}, 2, C F \mathrm{~s}, n$ are $\mathrm{CF}$ of elements $1,2, \ldots$, $n ; P L I>1$ denotes significant contamination.

Table 3: Classification of Soil Pollution Load Index (PLI)

\begin{tabular}{|c|c|c|c|c|c|c|}
\hline $\begin{array}{l}\text { PLI } \\
\text { Value }\end{array}$ & $0<1$ & $1<2$ & $2<3$ & $3<4$ & $4<5$ & $5<6$ \\
\hline $\begin{array}{l}\text { Soil } \\
\text { Quality } \\
\text { (Jorfi et } \\
\text { al } \\
\text {,2017) }\end{array}$ & Unpolluted & $\begin{array}{l}\text { Moderately } \\
\text { polluted to } \\
\text { unpolluted }\end{array}$ & $\begin{array}{l}\text { Moderately } \\
\text { polluted }\end{array}$ & $\begin{array}{l}\text { Moderately to } \\
\text { Highly } \\
\text { polluted }\end{array}$ & $\begin{array}{l}\text { Highly } \\
\text { Polluted }\end{array}$ & $\begin{array}{l}\text { Very } \\
\text { Highly } \\
\text { Polluted }\end{array}$ \\
\hline
\end{tabular}

\section{SOIL GEOACCUMULATION INDEX}

The index of Geoaccumulation $\left(I_{\text {geo }}\right)$ is widely used in the assessment of contamination of the soil by comparing the levels of heavy metals obtained to background levels originally used with bottom sediments (Atiemo et al., 2011). It is calculated using the equation: $I_{g e o}=\log 2($ $\mathrm{C}_{\mathrm{n}} / 1.5 \mathrm{~B}_{\mathrm{n}}$

where $C_{n}$ is the measured concentration of the elements studied and $B n$ is the value of Geochemical Background value of the element in fossil argillaceous sediment (average shale) as provided by Kabata- Pandias, (2011). And 1.5 is the constant, allowing for an analysis of the variability of heavy metals as a result of natural processes. $I_{\text {geo }}$ values are helpful to divide soils into quality classes (Nowrouzi \& Pourkhabbaz, 2014). The geoaccumulation index is classified as follows:

Table 4: Classification of Soil Geoaccumulation Index ( $\left.\mathbf{I}_{\text {geo }}\right)$

\begin{tabular}{|l|l|l|}
\hline$I_{\text {geo }}$ Class & Igeo Value $_{\text {ged }}$ & Soil Quality \\
\hline 0 & $I_{\text {geo }} \leq 0$ & Practically Uncontaminated \\
\hline 1 & $0 \leq \mathrm{I}_{\text {geo }} \leq 1$ & Uncontaminated to moderately Contaminated \\
\hline 2 & $1 \leq \mathrm{I}_{\text {geo }} \leq 2$ & Moderately contaminated \\
\hline 3 & $2 \leq \mathrm{I}_{\text {geo }} \leq 3$ & Moderately Contaminated to Heavily Contaminated \\
\hline 4 & $3 \leq \mathrm{I}_{\text {geo }} \leq 4$ & Heavily Contaminated \\
\hline 5 & $4 \leq \mathrm{I}_{\text {geo }} \leq 5$ & Heavily to Extremely Contaminated \\
\hline 6 & $5<\mathrm{I}_{\text {geo }}$ & Extremely Contaminated \\
\hline
\end{tabular}

\section{BIOACCUMULATION FACTOR (BIOCONCENTRATION FACTOR)}

Bioaccumulation factor $(\mathrm{BCF})$ is defined as the transfer and deposition of heavy metal from soil to edible part of plants which serves as the major route of entry of potentially toxic metals into the food chain (Chen et al., 2011). The nature and degree of transfer and bioaccumulation of the potentially toxic heavy metals to plants vary depending upon certain factors including species of plant, concentration and nature of the heavy metals, physicochemical properties of the soil and some other factors (Sharma et al., 2018). BCF is further defined as the ratio of metal concentration (fresh weight) in the edible part of plant to the total metal concentration in the soil (dry weight). BCF is used to determine the transfer potential of heavy metals from soil to plants as well as to estimate their potential human health risks (Zheng et al., 2007). BCF is computed as follows: 
$B C F=C r / C s$ where $\mathrm{Cr}$ and $\mathrm{Cs}$ stand for the heavy metal concentration in plant and soil respectively.

\section{Results and Discussion}

The texture of the soils studied were mostly sandy loam while the $\mathrm{pH}$ values were mostly alkaline in line with the findings of Dawaki et al., 2013. The soils were mostly salted as the electrical conductivity in most of the sites were above the $4000 \mu \mathrm{S} / \mathrm{cm}$ limits as recommend by FAO for irrigation soils.

The soils heavy metals content from three (3) different locations along Rivers Jakara and Getsi were presented in Table 5 and 6 . The coefficient of variation $(C V>0.71)$ of the samples was high and in most of the elements analyzed, a $p$ values $<0.05$ indicates high extent of spatial variation and higher degree of contribution from anthropogenic activities (point pollution). The Positive value of Skewness in $\mathrm{Zn}, \mathrm{Fe}, \mathrm{Pb}, \mathrm{Cd}, \mathrm{As}, \mathrm{Ni}, \mathrm{Co}$ and $\mathrm{Mn}$ showed that their values are lower than the average values while the positive Kurtosis in Fe and Mn only shows that most of the results of these elements aggregated close to the average value and that most values of the other elements took extreme values. The result also shows $\mathrm{Ni}$ and $\mathrm{Hg}$ had values below the approved limits. Ako et al., 2014 reported higher levels of $\mathrm{Pb}, \mathrm{As}, \mathrm{Ni}$ and $\mathrm{Mn}$ in soil samples from Luku area of Niger State in Nigeria. Bioavailability of heavy metals depends on soil $\mathrm{pH}$ (Zhou et al., 2019), lower soil $\mathrm{pH}$ and higher abundance of organic matter favour heavy metals uptake by crops (Hu et al, 2017; Hou et al., 2019; Eid et al., 2020; Liu et al., 2020 and Ouyang et al., 2020). Alkaline pH lowers heavy metals solubility (Swiatek et al., 2019), therefore alkaline soil retain heavy metals.

Table 5: Descriptive Statistics of Heavy Metals content in Soil samples collected from River Jakara. $\mathrm{n}=9$

\begin{tabular}{|l|l|l|l|l|l|l|l|l|l|l|l|}
\hline $\begin{array}{l}\text { Metal } \\
(\mathrm{mg} / \mathrm{Kg})\end{array}$ & $\mathrm{Zn}$ & $\mathrm{Cu}$ & $\mathrm{Cr}$ & $\mathrm{Fe}$ & $\mathrm{Pb}$ & $\mathrm{Cd}$ & $\mathrm{As}$ & $\mathrm{Ni}$ & $\mathrm{Co}$ & $\mathrm{Mn}$ & $\mathrm{Hg}$ \\
\hline Range & 184.11 & 83.81 & 95.27 & 910.57 & 72.32 & 14.33 & 26.33 & 39.01 & 15.09 & 303.13 & 0.19 \\
\hline Mean & 204.84 & 281.35 & 152.29 & 1517.58 & 110.9 & 14.23 & 29.00 & 34.64 & 17.39 & 385.7 & 0.16 \\
\hline Std. Dev & 73.14 & 26.78 & 32.69 & 279.26 & 23.63 & 4.94 & 9.18 & 11.74 & 5.33 & 92.14 & 0.07 \\
\hline FAO/WHO Limits & 50.00 & 20.00 & 100.00 & 425.00 & 10.00 & 3.00 & 14.00 & 50.00 & 8.00 & 2000.00 & 0.30 \\
\hline Skewness & -0.40 & 0.87 & -0.20 & 0.58 & 0.36 & -0.22 & -0.23 & 0.20 & 0.65 & 0.90 & 0.45 \\
\hline Kurtosis & -1.68 & 0.14 & -1.20 & 0.16 & -0.72 & -1.17 & -1.07 & -0.10 & -0.49 & 0.91 & -0.88 \\
\hline CV & 0.83 & 0.51 & 0.62 & 0.89 & 0.95 & 0.83 & 0.42 & 0.64 & 0.61 & 0.89 & 0.95 \\
\hline
\end{tabular}

Table 6: Descriptive Statistics of Heavy Metals content in Soil samples collected from River Getsi. $\mathbf{n}=9$

\begin{tabular}{|l|l|l|l|l|l|l|l|l|l|l|l|}
\hline $\begin{array}{l}\text { Metal } \\
(\mathrm{mg} / \mathrm{Kg})\end{array}$ & $\mathrm{Zn}$ & $\mathrm{Cu}$ & $\mathrm{Cr}$ & $\mathrm{Fe}$ & $\mathrm{Pb}$ & $\mathrm{Cd}$ & $\mathrm{As}$ & $\mathrm{Ni}$ & $\mathrm{Co}$ & $\mathrm{Mn}$ & $\mathrm{Hg}$ \\
\hline Range & 121.85 & 316.13 & 119.33 & 2220.73 & 105.44 & 15.97 & 46.02 & 38.24 & 32.25 & 436.00 & 0.25 \\
\hline Mean & 123.85 & 185.58 & 160.14 & 2548.89 & 95.44 & 10.43 & 53.03 & 56.7 & 24.66 & 473.66 & 0.19 \\
\hline Std. Dev & 48.27 & 142.21 & 39.53 & 764.98 & 33.50 & 4.75 & 14.57 & 11.69 & 10.48 & 149.75 & 0.08 \\
\hline $\begin{array}{l}\text { FAO/WHO } \\
\text { Limits }\end{array}$ & 50.00 & 20.00 & 100.00 & 425.00 & 10.00 & 3.00 & 14.00 & 50.00 & 8.00 & 2000.00 & 0.30 \\
\hline Skewness & 0.78 & 0.86 & -0.59 & 0.47 & 1.02 & 0.39 & 0.341 & -0.09 & -0.03 & 0.49 & 0.15 \\
\hline Kurtosis & -1.53 & -1.66 & -0.49 & -0.95 & 0.65 & 0.25 & -0.45 & -0.37 & -0.96 & -0.63 & 0.78 \\
\hline CV & 0.99 & 0.85 & -0.99 & 0.84 & 0.83 & 0.81 & 0.93 & 0.52 & -0.81 & 0.93 & 0.95 \\
\hline
\end{tabular}

The values of Pearson's correlation coefficient $(p$ value $=0.05)$ showed strong correlation between $\mathrm{Zn}, \mathrm{Fe}, \mathrm{Pb}, \mathrm{Cd}, \mathrm{Mn}$ and $\mathrm{Hg}(>0.83)$ and moderate correlation between $\mathrm{Cu}$ and $\mathrm{Cr}$, $\mathrm{Ni}$ and $\mathrm{Co}(<0.65)$ in samples collected from River Jakara. Similarly, a strong correlation was also observed in $\mathrm{As}, \mathrm{Zn}, \mathrm{Cu}, \mathrm{Fe}, \mathrm{Pb}, \mathrm{Hg}, \mathrm{Cd}$, and $\mathrm{Mn}$, in samples collected from River Getsi. 
This suggested their anthropogenic source as the area. Similarly, Gebeyehu and Bayissa (2020) reported an excessive higher levels of Fe and Mn and McGrath et al., 2001 reported values of up to $80,000 \mathrm{mg} / \mathrm{Kg}$ of Fe while Bello et al., 2019 reported lower values and FosuMensah et al., 2017 reported values of $\mathrm{Zn}, \mathrm{Pb}, \mathrm{Cu}$ and above the findings of this work in some selected sites in Kole Lagoon area of Ghana.

Table 7: Soil Contamination Factors of Soil Samples collected from six sites along Rivers Jakara and Getsi

\begin{tabular}{|l|c|l|l|l|l|l|l|l|l|l|l|}
\hline Heavy Metal/Site & & & & & & & & & & & \\
& $\mathrm{Zn}$ & $\mathrm{Cu}$ & $\mathrm{Cr}$ & $\mathrm{Fe}$ & $\mathrm{Pb}$ & $\mathrm{Cd}$ & $\mathrm{As}$ & $\mathrm{Ni}$ & $\mathrm{Co}$ & $\mathrm{Mn}$ & $\mathrm{Hg}$ \\
\hline Zungeru & 4.42 & 15.57 & 1.28 & 3.06 & 12.7 & 5.79 & 2.09 & 0.66 & 1.98 & 0.16 & 0.57 \\
\hline Airport Road & 5.56 & 13.70 & 1.76 & 3.33 & 11.06 & 5.36 & 1.93 & 0.78 & 2.39 & 0.19 & 0.60 \\
\hline P.R.P & 2.27 & 12.95 & 1.84 & 4.25 & 9.70 & 2.97 & 2.20 & 0.58 & 2.13 & 0.22 & 0.40 \\
\hline Gama & 1.75 & 4.70 & 1.99 & 4.22 & 6.83 & 2.34 & 3.01 & 0.96 & 2.91 & 0.16 & 0.50 \\
\hline Gayawa & 1.96 & 4.40 & 1.64 & 5.82 & 8.84 & 3.12 & 3.69 & 1.26 & 3.64 & 0.22 & 0.76 \\
\hline Getsi & 3.70 & 18.74 & 1.16 & 8.19 & 13.10 & 4.98 & 4.50 & 1.14 & 2.32 & 0.32 & 0.80 \\
\hline
\end{tabular}

The result of contamination factor is presented in Table 7. The potentially toxic element $(\mathrm{Cu})$ has the highest contamination factor of 18.74 in Getsi along River Getsi followed by the same $\mathrm{Cu}$ in Zungeru Road along River Jakara with 15.37. Cu contamination was also seen in Airport Road and P.R.P. Lead followed Cu with a pollution factor 13.10 and 12.7 in Getsi and Zungeru Road respectively. Another metal with a high degree of contamination 8.19 is Iron in Getsi site. The metals $\mathrm{Cr}, \mathrm{Cd}$, As and $\mathrm{Co}$ have moderate degree of contamination while Mn, Hg and Ni have very lower. However, Benedicta et al (2017) reported a higher factor in $\mathrm{As}, \mathrm{Cd}, \mathrm{Hg}$ and $\mathrm{Pb}$ in Korle Lagoon area of Accra Ghana. The result obtained suggested that the Getsi and Zungeru sites were heavily contaminated with $\mathrm{Cu}$ and $\mathrm{Pb}$ while Fe heavily contaminated Getsi. While moderate degree of contamination of $\mathrm{Fe}, \mathrm{Zn}, \mathrm{Cr}$, $\mathrm{Cd}$, As and Co were observed in Gama, Gayawa, Airport road and P.R.P. The metals Mn and $\mathrm{Hg}$ were found not to have contaminated the soils from the six sites where samples were collected while $\mathrm{Ni}$ only slightly contaminated Gayawa and Getsi and a very low contamination by $\mathrm{Cr}$ in all the sites. The Pollution Load index in all the six sites where samples were collected was found to be above 1 presenting a combine effect of the different heavy metals analyzed. The contamination by these three heavy metals could be due to increasing activity of metal scrap vendors, auto mechanics and burning of tyres for the wires along the River banks.

Table 8: Degree of Contamination (Cd) and Pollution Load Index (PLI) of Soil collected from six sites along Rivers Jakara and Getsi

\begin{tabular}{|l|l|l|l|l|l|l|}
\hline Site & Zungeru & Airport & P.R.P & Gama & Gayawa & Getsi \\
\hline$C d$ & 4.39 & 4.24 & 3.59 & 2.67 & 3.21 & 5.36 \\
\hline PLI & 1.36 & 1.35 & 1.34 & 1.31 & 1.33 & 1.38 \\
\hline
\end{tabular}

The result of Pollution Load index (PLI) and Soil Degree of Contamination $(C d)$ were presented in Table 8. The Highest $C d$ and PLI were found at Getsi site with 5.35 and 1.38 respectively. The values when compared with the classification made by Zahran et al, (2015) and Rahman et al, (2012) suggested a highly to extremely contaminated soil and was followed by soil samples collected from Zungeru site having a $C d$ and PLI values of 4.39 and 1.36 respectively. The lowest $C d$ and PLI were 2.67 and 1.31 respectively found in Gama suggesting a considerable degree of contamination based on the above classification. 
Table 9: Geoaccumulation Index of Soil Samples collected from six sites along Rivers Jakara and Getsi

\begin{tabular}{|c|c|c|c|c|c|c|c|c|c|c|c|}
\hline Heavy metal/Site & $\mathrm{Zn}$ & $\mathrm{Cu}$ & $\mathrm{Cr}$ & $\mathrm{Fe}$ & $\mathrm{Pb}$ & $\mathrm{Cd}$ & As & $\mathrm{Ni}$ & Co & $\mathrm{Mn}$ & $\mathrm{Hg}$ \\
\hline Zungeru & 0.63 & 1.59 & 0.43 & 0.62 & 0.93 & 1.17 & 0.85 & 0.23 & 0.38 & 0.14 & 0.11 \\
\hline \multirow[t]{2}{*}{ Airport Road } & & & & & & & & & & 0.15 & \\
\hline & 0.79 & 0.78 & 0.60 & 0.67 & 0.83 & 1.10 & 0.79 & 0.28 & 0.48 & & 0.12 \\
\hline P.R.P & 0.33 & 0.74 & 0.51 & 0.86 & 0.71 & 0.58 & 0.91 & 0.20 & 0.44 & 0.18 & 0.07 \\
\hline Gama & 0.25 & 0.27 & 0.67 & 0.84 & 0.51 & 0.47 & 1.24 & 0.34 & 0.61 & 0.15 & 0.09 \\
\hline Gayawa & 0.28 & 0.25 & 0.55 & 1.14 & 0.63 & 0.64 & 1.55 & 0.44 & 0.74 & 0.17 & 0.14 \\
\hline Getsi & 0.53 & 1.92 & 0.39 & 1.61 & 0.98 & 0.97 & 1.87 & 0.40 & 0.51 & 0.26 & 0.15 \\
\hline
\end{tabular}

The result of Geoaccumulation index was presented in Table 4. The quality of soil was measured using the Igeo index of classification developed by (Nowrouzi and Pourkhabbaz, 2014). The results showed that all the six sites where samples were collected were not contaminated by $\mathrm{Zn}, \mathrm{Cr}, \mathrm{Pb}, \mathrm{Ni}, \mathrm{Co}, \mathrm{Mn}$ and $\mathrm{Hg}$. The results further showed that $\mathrm{Cu}$ moderately contaminated Zungeru and Getsi while Fe also moderately contaminated Gayawa and Getsi. As was found to have moderately contaminated all the three sites along River Getsi (Gama, Gayawa and Getsi). The contamination by As could be due to presence of wood processing factories along the River as it is used for wood preservation. Cadmium also moderately contaminated Zungeru and Airport Road site that has a large presence of Auto mechanics and a possibility of inappropriate battery recycling and disposal system.

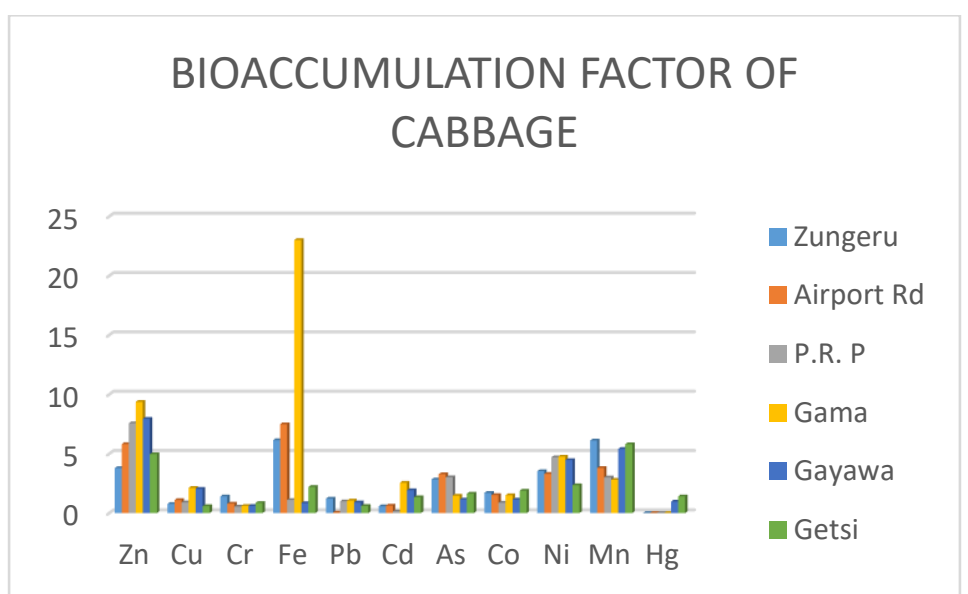

Figure 2: Bioaccumulation of Heavy Metals in Edible Part of Cabbage 


\section{BIOACCUMULATION FACTOR OF}

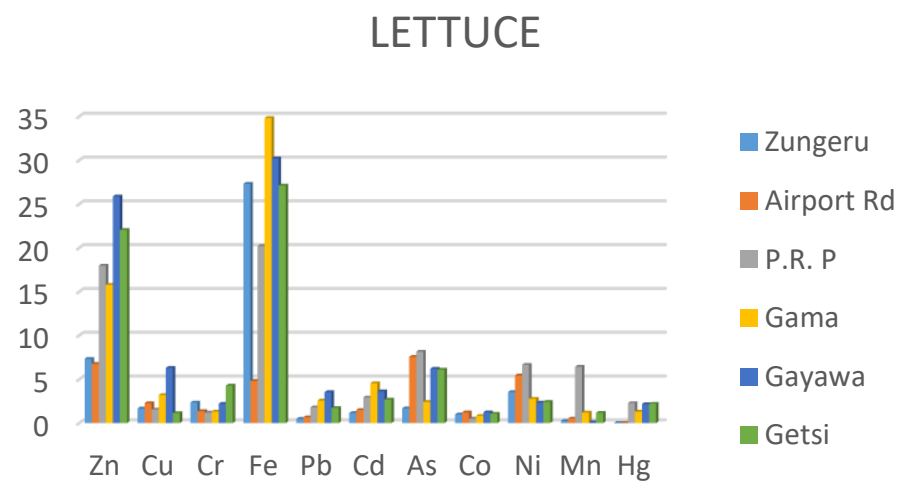

\section{Figure 3: Bioaccumulation of Heavy Metals in Edible Part of Lettuce}

The bioaccumulation factor of soil and vegetables (cabbage and lettuce) collected from six sites along River Jakara and Getsi were presented in Fig. 2 and 3. This study assessed the transferability of heavy metals from soil to cabbage and lettuce. The rate of transfer and bioaccumulation of heavy metals to plants depends on certain factors including the specie of the plant, level and properties of the heavy metal, physicochemical properties of the soil and many other factors (Sharma et al., 2018). From the result presented, it could be observed that the bioaccumulation factor is in these order of decreasing concentration, $\mathrm{Fe}>\mathrm{Zn}>\mathrm{Mn}>\mathrm{Ni}$ $>\mathrm{As}>\mathrm{Cd}>\mathrm{Cu}>\mathrm{Co}>\mathrm{Cr} \mathrm{Pb}>\mathrm{Hg}$ in cabbage while in lettuce is in this order, $\mathrm{Fe}>\mathrm{Zn}>\mathrm{As}$ $>\mathrm{Cu}>\mathrm{Ni}>\mathrm{Mn}>\mathrm{Cd}>\mathrm{Cr}>\mathrm{Pb}>\mathrm{Co}>\mathrm{Hg}$.

The result of this study showed that cabbage and lettuce accumulate more of Fe, $\mathrm{Zn}, \mathrm{Mn}$, As and $\mathrm{Ni}$ than other heavy metals analyzed and the BCF of most Metals were above $1(>1)$ suggesting a high transferability rate of the metals in the soil. The BCF values were then statistically analyzed by One-Way ANOVA to assess the significant difference in values obtained in cabbage and lettuce. The result of the analysis shows that $\mathrm{Fe}, \mathrm{Zn}$ and $\mathrm{Mn}$ significantly differ at $95 \%$ confidence limit with all the metals analyzed in cabbage while $\mathrm{Fe}$, $\mathrm{Zn}$ and Ni differ significantly with the other heavy metals analyzed in lettuce. Gebeyehu and Bayissa (2020) reported a high transferability of $\mathrm{Cu}$ from soil to tomatoes than it does in cabbage while $\mathrm{Hg}$ accumulates both in tomatoes and cabbage in some selected sites in Ethiopia.

\section{CONCLUSION}

This study determines the level of heavy metals in soil, cabbage and lettuce cultivated along Rivers Jakara and Getsi in Kano State Nigeria. The results indicated that levels of $\mathrm{Fe}, \mathrm{Pb}$ and As were above the approved FAO/WHO limits in both cabbage and lettuce while $\mathrm{Zn}, \mathrm{Cr}$, and $\mathrm{Cd}$ were found to be higher than the approved limit in most of the lettuce samples. The results of soil contamination factor show that $\mathrm{Cu}$ and $\mathrm{Pb}$ heavily contaminated Getsi and Zungeru sites while Fe heavily contaminated Getsi and a moderate contamination by Fe, Zn, $\mathrm{Cr}, \mathrm{Cd}$, As and Co were observed in Gama, Gayawa, Airport road and P.R.P. The metals Mn and $\mathrm{Hg}$ were found not to have contaminated the soils from the six sites where samples were collected while $\mathrm{Ni}$ only slightly contaminated Gayawa and Getsi and a very low contamination by $\mathrm{Cr}$ in all the sites. The Pollution Load index in all the six sites was found to be above 1 presenting a contamination by the combined effect of the different heavy metals analyzed while the Bioaccumulation factor or the soil -plant transfer coefficient were also found to be above 1 indication a high rate of transfer of the heavy metals from the soil to the edible parts of the vegetables especially Fe, Zn, Mn, Ni and As. 


\section{REFERENCES}

Ako, T.A., Onoduku, U.S., Oke, S.A., Adamu, I.A., Ali, S.E., Mamodu, A. and Ibrahim, A.T. (2014): Environmental impact of artisanal gold mining in Luku, Minna, Niger state, North-central Nigeria, J. Geosci. Geomat. 2(3): 28-37.

Antoniadis, V., Shaheen, S.M., Boersch, J., Frohne, T., Du Laing, G., Rinklebe, J. (2017). Bioavailability and risk assessment of potentially toxic elements in garden edible vegetables and soils around a highly contaminated former mining area in Germany. J. Environ. Manag.186: 192-200.

Atiemo, A., Francis, G.O., Kuranchie- Mensah, H., Osei, A.T., Linda, M.P. and Sarah, B. (2011): Contamination assessment of Heavy Metals in Road dust from Selected Roads in Accra, Ghana. Research Journal of Environmental and Earth Sciences, $3(5)$ : 473-480 ISSN: 2041-0492. Brady, N.C. and Weil, R.R. (2007): The Nature and Properties of Soils, 14th ed., Prentice Hall, Upper Saddle River, NJ, USA, 2007.pp1-20

Bazrafshan, E., Mohammadi, L., Ansari-Moghaddam, A. and Mahvi, A.H. (2015): Heavy Metals Removal

from Aqueous Environments by Electrocoagulation Process- A Systematic Review. J. Environ. Health Sci. Eng. 2015, 13, 74, 1-16. doi: 10.1186/s40201-015-0233-8.

Bello, S., Nasiru, R., Garba, N.N. and Adeyemo, D. J. (2019): Carcinigenic and nonCarcinogenic health

Risk assessment of heavy metals exposure from Shanono and Bagwai artisanal gold mines, Kano State Nigeria. Scientific African 6, e00197. http://doi.org/10.1016/j.sciaf.2019.c00197.

Benedicta Y. F., Emmanuel A., Dzidzo Y.T, and Frank N. (2017): Heavy metals concentration and distribution in soils and vegetation at Korle Lagoon area in Accra,Ghana. Environmental Chemistry, Pollution \& Waste Management 3: 1405887 https://doi.org/10.1080/23311843.2017.1405887.

Chen, C., Qian, Y., Chen, Q. and Li, C. (2011): Assessment of daily intake of toxic elements due to consumption of vegetables, fruits, meat, and seafood by inhabitants of Xiamen, China. J. Food Sci.; 76:T181-T188. https://doi.org/10.1111/j.17503841.2011.02341.x PMID: 21913923.

Dawaki, U M., Dikko, A.U., Noma, S.S. and Aliyu U. (2013): Heavy Metals and Physicochemical Properties of Soils in Kano Urban Agricultural Lands: Nigerian Journal of Basic and Applied Sciences. 21(3). 239-246.

Eid, E.M., Shaltout, K.H., Alamri, S.A.M., Seweelam N.A. and Galal T.M. (2020): Uptake prediction of tenHeavy Metals by Corchorus olitorius L. cultivated in soil mixed with sewage sludge. Food and Energy Security, 9: 1-13.

Fosu- Mensah, B.Y., Emmanuel A., Dzidzo Y. and Frank, N. (2017): Heavy Metals Concentration and distribution in soils and vegetables at Korle Lagoon area of Ghana, Cogent Environmental Sciences, (3):1405887. http://doi.org/10.1080/23311843.2017.1405887.

Gebeyehu, H.R. and Bayissa, L.T. (2020): Levels of heavy metals in soil and vegetables and associated health risks in Mojo area, Ethiopia. PLoSONE15(1):e0227883. https:// doi.org/10.1371/journal.pone. 0227883.

Hakanson, L. (1980): An ecological risk index for aquatic pollution control. A sedimentological approach. Water Res 14:975-1001.

Hu, B., Jia, X., Hu, J., Xu, D., Xia, F. and Li, Y. (2017): Assessment of Heavy Metal Pollution and Health Risks in the Soil Plant-Human System in the Yangtze River Delta, China. Int. J. Environ. Res. Public Health. 2017, 14 (9), 1042: 1-18. doi:10.3390/ijerph14091042.

Hu, W., Huang, B., Tian, K., Holm P.E. and Zhang, Y. (2017): Heavy metals in intensive greenhouse vegetable production systems along Yellow Sea of China: levels, transfer 
and health risk. Chemosphere 167, 82-90. Doi: 10.1016/j.chemosphere.2016.09.122. PMID: 27710846

Inengite, A.K., Abasi, C.Y., ... Walter, C. (2015): Application of pollution indices for the assessment of heavy metals pollution in flood impacted soil. International Research Journal of Pure and Applied Chemistry, 8, 175 - 189.

Inobeme, A., Ajai, A.I., Iyaka, Y.A., Ndamitso, M. and Uwem, B. (2014): Determination of

Physicochemical and Heavy Metal Content of Soil Around Paint Industries in Kaduna. Int. J. Sci. Technol. Res. 2014, 3 (8), 221-225.

Jorfi, S., Maleki, R., Jaafarzadeh, N. and Ahmadi, M. (2017): Pollution load index for heavy metals in Mian-Ab plain soil, Khuzestan, Iran. Data in Brief 15:584-590.

Kabata-Pendias, A. (2011): Trace elements of soils and plants Boca Raton: CRC press, Taylor \& Francis Group. 4th ed., pp. 28-534.

Kabir, E., Ray, S., Kim, K.H., Yoon, H.O., Jeon, E.H., Kim, Y.S., Cho, Y.S., Yun, S.T. and Brown, R.J.C. (2012): Current Status of Trace Metal Pollution in Soils Affected by Industrial Activities. Sci. World J. 2012, 1-18. https://doi.org/10.1100/2012/916705.

Loska, K., Wiechulab, D. and Korus, I. (2004): Metal Contamination of farming Soils affected by Industry. Environmental International, 30, 159- 165.

Machender, G., Dhakate, R., Prasanna, L. and Govil, P.K. (2011): Assessment of heavy metal contamination in soils around Balanagar industrial area, Hyderabad, India. Environ Earth Sci 63:945-953.

Nikolaidis, C., Zafiriadis, I., Mathioudakis, V. and Constantinidis, T. (2010): Heavy metal pollution associated with an abondaned Lead-Zinc mine in the Kirki Region, NE Greece. Bulletin of Environmental Contamination and Toxicology, 85, 307- 312.

Nowrouzi, M. and Pourkhabbaz, A. (2014): Application of geoaccumulation index and enrichment factor for assessment contamination in the sediments of Hara Biosphere Reserve, Iran. Chemical Speciation \& Bioavailability, 26, 99.

Ouyang, J., Liu, Z., Zhang, L., Wang, Y., and Zhou, L. (2020): Analysis of influencing factors of Heavy Metals Pollution in Farmlands-Rice system around a Uranium Tailings Dams. Process safety and Environmental Protection 139; 124-132.

Rahman, S.H., Khanam, D., Adyel, T.M., Islam, M.S., Ahsan, M.A. and Akbor, M.A. (2012): Assessment of heavy metal contamination of agricultural soil around Dhaka Export Processing Zone (DEPZ), Bangladesh: implication of seasonal variation and indices. Appl. Sci. 2:584-601.

Rakesh, S.M. and Raju, N.S. (2013): Correlation of Heavy Metal Contamination with Soil Properties of Industrial Areas of Mysore, Karnataka, India by Cluster Analysis. Int. Res. J. Environment Sci. 2013, 2 (10), 22-27.

Rodrigo-Comino, J. and Cerdà, A. (2017): Improving Stock Unearthing Method to Measure Soil Erosion Rates in Vineyards. Ecol. Indic. 2018, 85, 509-517. doi:10.1016/j. ecolind.2017.10.042.

Sayadi, M.H., Shabani, M., \& Ahmadpour, N. (2015): Pollution index and ecological risk of Heavy metals in the surface soils of Amir- Abad Areain Birjand City, Iran. Health Scope, 4, 121 - 137.

Shaapera, U., Nnamonu, L.A., Eneji, I.S. (2013): Assessment of Heavy Metals in Rana esculenta Organs from River Guma, Benue State Nigeria. Am. J. Anal. Chem. 2013, 4 (09), 496-500. doi:10.4236/ajac.2013.49063.

Sharma, S., Nagpal, A.K. and Kaur, I. (2018): Heavy metal contamination in soil, food crops and associated health risks for residents of Ropar wetland, Punjab, India and its environs. Food Chem. 2018; 255:15-22. https://doi.org/10.101 6/j.foodchem.2018.02.037

PMID: 29571461. 
Steffna, J.J., Brevika, E.C., Burgess, L.C. and Cerda, A. (2017): The Effect of Soil on Human Health: an Overview. Eur. J. Soil Sci. 2017, 1-13. doi:10.1111/ejss.12451.

Swiatek, B., Wos, B., Gruba, P., and Pietrzykowski, M. (2019): Bioaccumulation of heavy metals $(\mathrm{Pb}, \mathrm{Cd}, \mathrm{Cr}$, and $\mathrm{Cu})$ in fine roots uner the species of Alders (Alnus spp.) plantation at different Soil substrates addition on the reclaimed combustion wastes landfill. Water, Air and Soil Pollution, 230: 1-10.

T.W. Lane, F.M. Morel. (2009): A biological function for cadmium in marine diatoms, Proc. Natl. Acad. Sci. USA 9 (2009) 4627-4631 462-431.

Tomlinson, D.L., Wilson, J.G. and Geoffery, D.W. (1980): Problems in the assessment of heavy metals in estuaries and the formation of a pollution index. Helgolander Meeresunters 33, 566- 575. http:// doi.org/10.1007/BF02414780.

Tutic, A., Novakovic, S., Lutovac, M., Biocanin, R., Ketin, S., Omerovic, N. (2015): The Heavy Metals in Agrosystems and Impact on Health and Quality of Life. Maced. J. Med. Sci. 2015, 3 (2), 345-355. doi:10.3889/oamjms.2015.048.

Tylor, S.R. and McLennan, S.M. (1995): The geochemical evolution of the continental crust. Rev Geophys 33:241-265.

Wilson, B., Braithwaite, A., Brian. and Yatt F. (2005): An evaluation of procedures for the digestion of soils and vegetation from areas with metalliferous pollution. Toxicol. Environ. Chem. 2005; 87:335-344. https://doi.org/10.1080/02772240500165570.

Zahran, M.A.E., El-Amier, Y.A., Elnaggar, A.A., Mohamed, H.A.E. and El-Alfy, M.A.E. (2015): Assessment and distribution of heavy metals pollutants in Manzala Lake, Egypt. J Geosci Environ Protect 3:107-122.

Zheng, N., Wang, Q.C. and Zheng, D.M. (2007): Health risk of $\mathrm{Hg}, \mathrm{Pb}, \mathrm{Cd}, \mathrm{Zn}$, and $\mathrm{Cu}$ to the inhabitants around Huludao Zinc Plant in China via consumption of vegetables. Sci. Total Environ. 2007, 383, 81-89.

Zhou, Y., Jia, Z., Wang, J, Chen, L, Li, Y. and Zhou, S. (2019): Heavy Metals distribution, relationship and prediction in a wheat-Rice rotation system, Geoderman, 354; 1-11 